\title{
Post-Conference Postscript
}

\author{
JONATHAN HYSLOP*
}

University of Pretoria

The 2011 conference of the South African Historical Society was a remarkably invigorating event. Professional conferences can often be bland; but this one was characterised by the presentation a rich crop of work of excellent work on new themes; by intelligent, creative and focused debates; by the emergence of a new generation of talented young historians and an exciting infusion of visitors from the southern African region, especially from Botswana.

Looking at the conference alone one would assume that the historical profession was flourishing in South Africa, and one would be right. But what is remarkable is that this is occurring in an institutional context which is far from encouraging. As we will see later, this creative surge is taking place at the time when university bureaucracies are often refusing to make hard choices about the role of research policy and of issues of research ethics; when the higher education ministry wants universities to teach more students with less resources; when there is a disastrous near-collapse of the National Archives; and when the national political leadership would prefer political praise-singing to the ambiguities of serious historical inquiry. If southern African historians are doing well, it is despite, rather than because of, the institutional circumstances in which we find ourselves.

In this postscript, I survey both the exciting prospects opened up by the conference, and the serious threats which face contemporary South African historians. I also make some modest suggestions for future directions.

One of the most important interventions of the conference was Jacob Dlamini's keynote speech, dealing with the complexity of South Africa anti-apartheid struggle histories. Dlamini gave high, and justified, praise to Hugh Lewin's memoir, Stones Against the Mirror. ${ }^{1}$ In the book, Lewin, who was jailed in the 1960s for his participation in the sabotage campaign of the National Council of Liberation/African Resistance Movement, tells the story of his relationships with the two comrades who betrayed him. To one, he eventually becomes reconciled, to the other he does not. The book also deals in a profoundly thoughtful way with the author's ambivalent view of the use of political violence. As Dlamini rightly pointed out, Lewin's writing breaks, very creatively, out of the stereotypical registers of writing about South African political movements. Far too many struggle histories, struggle biographies and struggle memoirs are simply unreadable,

*Email: Jon.Hyslop@up.ac.za

1. H. Lewin, Stones Against the Mirror: Friendship in the Time of the South African Struggle (Cape Town: Umuzi, 2011). 
because they avoid the complexity which serious historical writing is capable of bringing to the understanding of human beings and the choices they make. Instead, much of the literature offer us cartoon-strip heroes and villains. Simplistic oppositions of good and evil and teleological narratives have been imposed on a world where clandestine connections across political boundaries, blurrings between criminality and commitment, and unpredictable endings were rife. This is surely a good moment to reassess whether the endless production of writing in the triumphalist register is actually taking forward our historical understanding.

Another noteworthy development at the conference was the exciting work of scholars such as Sue Onslow on the history of the Cold War and its impact on Southern Africa. This reflects a new energy in international Cold War studies. Whereas for many years research on the Cold War was dominated by rather dismal international relations and frameworks, in recent years there has been a flowering of historical work on the period informed by a strong interest in political cultures. A particular leading role in this has been played by Professor Odd Arne Westad and is reflected in his editorship of the Cambridge History of the Cold War. ${ }^{2}$

South African historians have tended to avoid engagement with the Cold War for good reasons. The apartheid government justified its actions in the name of anti-Communism and presented the liberation movements as stooges of the Soviet Union. But the result has been a tendency to interpret the Cold War pronouncements of the old regime's political and military leadership as simply a covers for their racism, and to portray the ANC's links with the Soviet bloc as simply a pragmatic alliance. Under closer scrutiny though, the picture is becoming less simple. While racism was undoubtedly central to all old regime ideology, anti-communist ideas were an important part of the thinking of its leadership, especially in the military, and had real effects on their actions. On the other hand, under the influence of the South African Communist Party, the ANC did undergo a clear alignment with Soviet political thinking. The world views of the regime and the opposition to it were importantly shaped by their respective identifications with, and connections to, the western and eastern blocs, and the effects of these commitments are important to understand. This is also significant for understanding contemporary South African politics. The fragmentation in economic policy in the years after apartheid can largely be explained by the unexpectedness of the demise of the USSR and the crisis this created for ANC thinking.

Along with the historical profession internationally, historians of South Africa are becoming increasingly interested in writing history which transcends international boundaries. The other keynote of the conference, from Professor Antoinette Burton, focusing on the travels in newly independent Africa of an Indian writer, provided a master class in the art of transnational history. Of course transnationalism should not be seen as an all-purpose remedy for the intellectual problems facing historians. The national state remains a vitally important part of our world and will continue to be so for the foreseeable future. But the turn to acknowledging the importance of social and political processes which take place across borders has had particularly salutary effects on South African historians, because the overwhelming nature of our society's internal problems have made

2. M. P. Leffler and O.A. Westad, eds., The Cambridge History of the Cold War (three volumes), (Cambridge: Cambridge University Press, 2011). 
us excessively inward-looking. This newly global perspective was reflected in a number of excellent contributions to the conference. Although it is invidious to single anyone out, Andrew MacDonald's study of the migrant career of an early twentieth-century international Kurdish con-man, who included South Africa in his international career of fraud was a work of brilliant scholarship, which promises great things to come from this outstanding young historian. ${ }^{3}$ Transnationalism also to some extent frees us from sterile debates about whether South African history should be nationally framed, part of African historiography or part of world history. Rather, it encourages us to follow the global linkages of local events wherever the trail leads, whether these be to other parts of Africa, to Asia, or to Europe.

Biographical writing is alive and well in South African historiography. There were a number of papers at the conference which made creative use of biographical strategies, and the conference also saw the launch of two important scholarly biographies, Hlonipa Mokoena's book on Mangena Fuze, and Heather Hughes' life of John Dube. ${ }^{4}$ Biography has often been regarded by academic historians as a somewhat 'low-rent' activity, but it has important virtues both intellectually and as a vehicle for bringing history to a wider audience. Far from being an easy option, biography challenges the author to address the fundamental sociological question of the relationship between structure and individual agency. And few forms of history are as demanding in their archival demands as serious biography. Moreover the inherently novelistic structure of biography makes it readable to a public which would never be tempted by other forms of historical writing. We hope to see a fruitful development of this field and a broadening reading public for South African biography.

The conference gave proof of the continuing development of high quality research in a number of important sub-fields of historical scholarship, including environmental history, feminist history and gay history. It was also clear has been important progress in professionalising the previously somewhat uneven field of South African military history, to which Ian van der Waag, Louis Grundligh and Albert Grundlingh have made very important contributions.

To ageing historians, the presence at the conference of a significant cohort of talented, capable and enthusiastic young South African and Botswanan historians was hugely encouraging. There has - especially since the disastrous downgrading of school history teaching during the South Africa's ill-starred Outcomes Based Education experiment - been much gnashing of teeth about the future of history. But here we saw a group of young people, questioning, capable and racially and culturally diverse, keen to take forward the teaching and writing of history.

Yet it is precisely this sense of optimism about the potential that must make us question and engage with some of the major obstacles which face the profession. If the potential of these young scholars is to be fulfilled, South African higher education must offer them an engaging and desirable future.

3. A. MacDonald, 'The Jilu Men and M.G. Daniel in the Benevolent Empire: A History of Transcontinental Begging c.1850-1950' (unpublished paper).

4. H. Mokoena, Magema Fuze: The Making of a Kholwa Intellectual (Pietermartizburg: University of KwaZulu-Natal Press, 2011); H. Hughes, The First President: A Life of John L. Dube, The Founding President of the ANC (Johannesburg: Jacana Media, 2011). 
And it is far from clear that the universities of South Africa are making academia an attractive career for bright young people. Instead of finding ways to adequately fund full time postgraduate studies, most universities are making use of MA and $\mathrm{PhD}$ students in full time teaching posts, thus endlessly prolonging the time it takes for these students to complete their higher degrees. In a world where the norm for appointment to a tenure-track post is a $\mathrm{PhD}$, this is an anachronism which undermines our international standing, as well as being bad for the personal development of the students involved.

And when the student does get appointed to a teaching post, administrations often fail to provide the conditions for quality teaching and research productivity. Desperate to placate a state which wants them to teach more and more students with less and less money, administrators are driving up the size of classes to the point where the classroom experience becomes alienating and ineffective for the student and dispiriting for the lecturer. Despite a continuing increase in the number of bureaucrats, more and more of academics' time is taken up by a constant drizzle of administrative tasks, many of them created by the misguided belief that anything can be measured.

What university planners fail to understand is that the working time of academic staff is an institution's greatest asset. The more time that academics spend on teaching and research, the better for all concerned. It is absurd that in many institutions, for want of adequate secretarial and technical support, scholars spend time filling in forms and trying to figure out how to project their Power Point. This may sound like the whingeing of the over-privileged. But for teaching effectiveness and research productivity this is a crucial question. Paying a PhD to do work that could be done by a clerk or a technician is an extraordinary waste of money. And administrators tend to believe that money is always the key to improving research. But, especially for historians, time is actually more important. You can always do cheaper research, but you cannot do your work without the time to get into the archives or do your field interviews. Research in the humanities is about time more than money.

It also needs to be said that in some cases - thankfully, by no means all - university administrations are failing to set adequate standards of ethical conduct, which contributes to making the university a less desirable place to work. Grossly sexist practices are winked at, often in the name of 'culture'. Ludicrous personal deference is expected by some authority figures in a way that stifles the ability of junior staff to participate in collegial life. And a time bomb under the credibility of South African universities is the question of plagiarism. Administrators in some institutions will privately acknowledge that plagiarism is a major problem, not only amongst students but academic staff as well. But complaints are hushed up for fear of public embarrassment (which of course is all the worse if the story gets out). Universities need to make it clear that plagiarism is the ultimate scholarly crime, and publicly to expose those who they discover engaged in it. A university cannot attract the best and brightest if your commitment to the ethic of professionalism is in doubt.

These issues need to be thought through by university administrators if they are to draw in the current crop of $\mathrm{PhD}$ graduates. These young people have other options - given the skill shortage in the economy, they will be head-hunted by government and industry. Nobody who knows academics will doubt that the vast majority go more than the extra mile every day in their commitment to teaching, research and institutional life. But they will only continue to do so if they work in institutions they can believe in. 
There are however, two areas of life beyond the university itself which also pose severe challenges to South African historians. The one concerns the state of the countries archival resources. The other, overlapping with it, affects the very health of democracy itself.

To enter the reading room of the National Archives of South Africa in Pretoria is to receive intimations of an institution in crisis. Despite having an excellent searchable database, which can be accessed on the other side of the world online, the NASA finds it impossible to provide a single computer terminal in the reading room on which the visitor can consult it. Hundreds of box files awaiting replacement tower shakily up one wall, evoking the image from E.M. Forster's novel, Howard's End, of the autodidact crushed to death by a falling bookcase. A group of genealogists, who treat the place as a social club, yack away unchecked by the staff, despite the pleading looks of those who are actually trying to do some work. The aura of employee demoralisation is so thick you could cut it. These are just the superficial signs of the chaos which has raged in the archive since the departure of its previous director and the government's failure to appoint a new one. At a deeper level - in the vaults - there are clearly problems with the cataloguing of material and political pressures holding up access to the 'hot' documents of the apartheid era. How well the rich holdings of the currently shut Johannesburg Public Library will survive the current renovations is unclear, but past experience does not inspire confidence. Stephen Gray some years ago recounted how he had resigned from the board of the library after the council announced a zero budget for new acquisitions and stacks in the basement were deluged with sewage.

To be fair to government, the gracious old National Library in Cape Town has a good reputation amongst researchers and the new National Library in Pretoria is an elegant and impressive building and has courteous and helpful staff. But the state of the National Archives is not just an inconvenience to researchers. It endangers the very survival of the record of South Africa's past. There were many discussions amongst scholars over the past two decades of the nature of the archive and of the need to expand it beyond the narrow definition of a collection of papers. This was most innovative and creative. But it may have rested on the false assumption that the basic collection and protection of historical documents was a problem that had had already been solved. This turns out not to be the case. We now need to save our endangered paper archive as a matter of urgency.

Closely connected to this problem is the imminent threat to access to archival sources posed by South Africa's new information act. There is no doubt that this odious piece of legislation is going to pose serious problems for those researching recent history. An increasingly paranoid state is likely to use its extensive powers to classify documents which the public needs to know about. It is both in our professional interest and our duty as citizens to protest against this development.

South African historians can look back over the last few decades, with a degree of modest satisfaction. A really substantial national historiography has been created. Of course there will be occasional declarations by politicians that 'our history remains unwritten', but that simply reflects ignorance of what work has to been done. Critics of the historical profession will also wheel out the charge of 'ivory towerism' against us. But South African historians have nothing to be ashamed about in terms of our level of public engagement. Certainly, we can always do better, but the contributions of scholars to history 
curricula and teacher education, museums and heritage, work with community organisations and popularisation are substantial.

But we cannot rest on these achievements. An increasingly globalised scholarship is posing new research questions. We need to continue to find new ways to engage with wider publics, especially in a time when the consciousness of the young is being shaped by new media, with its inbuilt 'presentism'. Authoritarian enemies of free speech and free thought need to be countered. But most importantly for our professional obligation, we need to fight for universities give the an outstanding cohort of young historians the opportunities, support and working conditions they need to emerge as mature teachers and scholars. 